\title{
Terörün Volatilitiye Etkisi: Türkiye BIST 100 Endeksinde Bir Uygulama
}

\author{
Esengül BACIK ${ }^{*}$, Mustafa ÖZER**, Serpil ALTINIRMAK ${ }^{* * *}$ \\ ÖZ
}

Terör, Türkiye'nin ve Dünya devletlerinin ortak sorunudur. Terör faaliyetlerinin en büyük maliyeti birçok insanın hayatını kaybetmesidir. Aynı zamanda, terörizmin; sosyal, ekonomik, siyasi ve psikolojik anlamda da birçok yıkıcı etkisi bulunmaktadır. Terör eylemlerinden sonra karar verici ve uygulayıcı birimlerin algı ve duygu durumları farklılaşmaktadır. $\mathrm{Bu}$ farklılaşmanın sonucunda oluşan olumsuzluklar uluslararası ticaret yoluyla bütün dünyaya yayılmaktadır. Terör eylemleri finansal piyasalar üzerinde de etkili olabilmektedir. Fonlar, piyasayı terk ederken, fiyatlar düşmekte ve faiz oranları yükselme baskısı altında kalmaktadır. Gelişmekte olan ülkelerde bu etkiler daha uzun süreli olabilmektedir. Bu çalışmada ise, terör ile volatilite arasında doğrudan ya da dolaylı olarak herhangi bir ilişki olup olmadığı araştırılmaktadır. Terör ile ortaya çıkan korkunun hisse senetleri getirilerine yansıyıp yansımadığı incelenmektedir. DATASTREAM veri sisteminden elde edilen 312 aylık veriler kullanılarak BİST 100 endeksi piyasa getirilerinin volatilite grafiği Component GARCH yöntemi ile elde edilmiştir.

Anahtar Kelimeler: Terör, Volatilite, GARCH, BIST-100

JEL Sinıflandırması: G14, G18

\section{Impact of Terrorism to Volatility: An Application on BIST 100 Index in Turkey}

\begin{abstract}
Terror is considered as the common problem of both Turkey and other nations in the world. Terrorism cost loss of many lives. It can also create social, economic, political and psychological destructive effects. Following the terrorist attacks, there could be a change in the perception of the decision and policy makers. The negative outcomes of such changes will later be spread to other countries via international trade. Terrorist activities can also adverse effects on financial markets. Outflow of funds from the countries create a downward pressure on stock prices and upward pressure on interest rates. These effects can create long lasting effects in developing countries than developed. In this study, we investigate the direct and indirect relationship between terrorism and stock market volatility by using component GARCH model for the monthly data extracted from DATASTREAM over the period January 1990 and December of 2015 .
\end{abstract}

Keywords: Terror, Volatility, Component GARCH, BIST-100

JEL Classification: G14, G18

\footnotetext{
* Öğrenci., esenn_23@hotmail.com

** Prof.Dr., Anadolu Üniversitesi, İIBBF, İktisat Bölümü, muozer@anadolu.edu.tr

****Doç.Dr., Anadolu Üniversitesi, Eskişehir Meslek Yüksekokulu, Toptan ve Perakende Satış Bölümü, saltinirmak@anadolu.edu.tr
} 


\section{GİRIŞ}

Terör, tüm dünya devletleri için kanser hastalığına benzetilir. Terör olaylarının yaşanmasıyla birlikte toplumsal bir korku oluşur ve zamanla ekonomik, siyasi, sosyal, kültürel ve psikolojik yönden önemli sonuçlar doğurur. Eğer bir ülke terör sorununun üstesinden gelebilirse sağlığına kavuşur, aksi halde sorun giderek büyür ve tedavisi imkânsız hale gelir. Terörist saldırıların etkileri; ülkeler, sektörler ve zamana yayılan etkiler gibi birçok faktöre bağlı olarak değişim göstermektedir. Bu faktörler arasında saldırıların mahiyeti, çarpan etkileri, saldırılar karşısında uygulanan politikalar (hareket tarzı) ve piyasaların dayanıklılığı da yer almaktadır (Ağırman, Özcan ve Yılmaz, 2014).

Abadiea ve Gardeazabalb (2008), terörün dünya ekonomileri üzerine etkilerini inceledikleri çalışmalarında iktisadi bir bakış açısıyla terörün dört temel etkiye sahip olduğunu ortaya koymaktadırlar. Bunlardan ilki, insani ve fiziksel sermayenin terör saldırıları neticesinde azalmasıdır. İkincisi, terör saldırıları ile oluşan korku ortamının yüksek oranda belirsizliğe neden olduğudur. Üçüncüsü, terör olaylarındaki artışın terörün önlenmesi için yapılması gerekli güvenlik harcamalarında da bir artışa neden olduğudur. Bu artış ülke kaynaklarının çok daha verimli sektörlerden güvenlik harcamalarına kaydırılmasıyla gerçekleştirilmektedir. Dördüncüsü ise terörün turizm gibi belli başlı bazı sektörleri doğrudan etkilemesidir (Enders, Sandler ve Parise, 1992: 21).

Finansal piyasalar finansal sistemin temel dayanağıdır. Piyasaların işleyiş̧i ne kadar düzenli ve iyi olursa finansal sistem de o kadar sağlıklı olur. Finansal piyasaları olumsuz yönde etkileyen en temel unsurlar arasında belirsizlik yer almaktadır. Terör faaliyetleri ise, bu belirsizliği tetikleyen faktörlerdendir. Terör olaylarının yaşanması başta turizm olmak üzere birçok sektörde, yatırımlarda, dış ticarette, tarım ve hayvancılıkta ve diğer pek çok alanda yıkıcı etkiler yaratır ve bu etkiler doğrudan veya dolaylı olarak finansal piyasalara yansır. Öncelikle mikro ekonomik dengeler ve beraberinde makroekonomik dengeler sarsilir. Finansal piyasalardaki globalleşme dikkate alındığında, terörün sadece ilgili ülkenin finansal piyasalarını değil diğer ülkeleri de etkileyebileceği görülecektir.

Ülkelerde belirsizlik ortamının hâkim olması, finansal piyasalarda volatilitenin de artmasına sebebiyet verir. Finansal piyasalarda oynaklıklar, tüketim harcamaları ve yatırım harcamalarını etkileyerek ekonomik faaliyetler üzerinde etkili olabileceği gibi; finansal sistemin işleyişini de bozarak yapısal ve idari düzenlemelerin yapılmasına da neden olabilir (Becketti ve Sellon, 1989). Artan enflasyonist beklentiler, daraltıcı para politikası uygulamaları ve faiz oranları üzerindeki kontrollerin kaldırılması ile hızlanan faiz oranı oynaklıkları da reel ekonomik maliyetler yaratabilmekte ve finansal sistemin işleyişinde önemli kesintilere yol açabilmektedir (Özer ve Türky1lmaz, 2004: 5).

Türkiye özellikle Cumhuriyetin kuruluşundan beri 92 yıllık bir süreçte çok sayıda terör olayına sahne olmuştur. Terörün karakteristik özelliği olan yıkıcı etkiler, Türkiye'de de birçok alanda hissedilmiştir. Özellikle terör faaliyetlerinin yoğunlaştığı bölgelerde güvenlik harcamalarındaki artış, turizm gelirlerinin baltalanması, terör nedeniyle iç göçlerin yaşanması ve kaynakların verimli kullanılamaması, eğitim sürecinin aksaması gibi birçok faktör terörün maliyetlerini arttırmaktadır. Yaşanan can kayıpları için ise kurulabilecek herhangi bir cümle bulmak imkânsızdır.

$\mathrm{Bu}$ çalışmanın amacı, terör eylemlerinin finansal piyasalardaki oynaklığa etkisini Türkiye'de BIST 100 endeksi üzerinde incelemektir. Bu amaçla 1990-2015 dönemleri arasında DATASTERAM den elde edilen 312 aylık veriler kullanılarak BİST 100 endeksi oynaklığ GARCH yöntemi ile hesaplanmıştır.

Finansal piyasalarda oynaklığa ilişkin birçok çalışma olmasına rağmen spesifik olarak terörün volatiliteye etkisini ele alan pek fazla çalışma bulunmamaktadır. Bu bağlamda yapılan 
çalışma, bu konuda yapılacak olan diğer çalışmalara yol gösterici nitelikte olacaktır. Öte yandan terör ile volatilite arasında doğrudan ya da dolaylı olarak herhangi bir ilişki olup olmadığı sorgulanacaktır. Terör ile ortaya çıkan korkunun hisse senetleri getirilerine yansıyıp yansımadığı ele alınacaktır.

\section{TÜRKIYE'DE TERÖRIZM}

Türkiye Cumhuriyeti kuruluşundan itibaren varlığına ve ulusal güvenliğine yönelik çeşitli tehditlerle karşılaşmıştır. Bu tehditler, kimi zaman topraklarının bir kısmına, toprak bütünlüğüne, karasuları ve hava sahası gibi konularda egemenlik haklarına yönelik olabilmiştir (Bahçeşehir Üniversitesi, 2008: 3).

Türkiye'nin maruz kaldiğ ve halen süregelen terörizm tehdidinin belirgin iki özelliği vardır: Illk özellik; etnik, radikal dinci ve ideolojik olmak üzere neredeyse bilinen tüm terörizm türlerinin Türkiye' de ortaya çıkmış olmasıdır. İkincisi de karşılaşılan tüm terörizm tehditlerinin arkasında güçlü bir dış desteğin varlı̆̆ını hissettirmesidir (Türkiye Barolar Birliği [TBB], 2006: 532).

Kronolojik olarak bakıldiğında, 1960'ların sonu ile 1980'li yıllar arasında Asala terörü, 1970-1980 yılları arasında ideolojik terörizm olarak "sağ-sol çatışması", 1980'lerden sonra etnik ayrılıkçı terörizm olarak "PKK terörizmi”, 1990'll yıllarının sonundan itibaren de dini motifli terörizm olarak "Tevhid-i Selam (Kudüs Ordusu), Hizbullah, El Kaide ve IŞID” tehdidiyle karşılaşmıştır. Terörizm Türkiye'de on binlerce insanın ölümüne, daha çok sayıda insanin yaralanmasina veya sakat kalmasina neden olmustur ve ciddi ekonomik kayıplar ortaya çıkmıştır. Sadece 1984 sonrasındaki etnik /ayrılıkçı terörizmin faturasının 100 Milyar doların üzerinde olduğu tahmin edilmektedir. 1984-2004 periyodunda Türkiye'de meydana gelen terör olaylarının sayısı ise 51.500 civarındadır. Bu olayların yaklaşık 22.000'i (\% 43) etnik/ayrılıkçı terörizm kaynaklıdır (TBB, 2006: 531-532).

Günümüzdeki etnik terörizm tehdidinin en önemli kaynă̆g, Kürt etnisitesinin temsilcisi rolüne soyunan $P K K^{\prime} d \imath$. Bir diğer etnik terörizm odağ olan Ermeni terörist örgütleri ise, ASALA başta olmak kaydlyla potansiyel tehdit pozisyonunda bulunmaktadırlar. 1984-1992 yıları arasinda giderek artan bir terörizm tehdidi oluşturan PKK, 1992'den itibaren Türkiye'nin terörle mücadele konseptini değiştirmesi sonucunda 10 ylllk bir gerileme süreci yaşamış, Abdullah Öcalan'ın Kenya'da yakalanmasindan sonra da PKK kaynakl terörizm algılamalart güçlü ve yakın potansiyel tehdit konumuna doğru yönelmiştir. Bu aşamada, çeşitli dış ve iç konjonktürel gelişmeler Kürt etnik terörizminin tehdidini yeniden yükseltmis ve güçlendirmiştir (TBB, 2006:547).

PKK terör örgütü, 1984'ten beri birçok kanlı eylem gerçekleştirmiş, bu eylemler çok sayıda cana mal olmuştur. Türkiye'de son yıllarda terörle mücadele kapsamında bir çözüm sürecine girilmesine rağmen halen saldırılar devam etmekte ve birçok kişi hayatını kaybetmektedir. Terörün hala önüne geçilememesi ülke gelişiminin önündeki barikatı da güçlendirmektedir. Türkiye'de refah ve huzurun sağlanması durumunda gelişim ve değişim sürecine daha hızlı ayak uydurulacaktır.

Genel olarak Türkiye'de yaşanan terör eylemleri, ülkenin Doğu ve Güneydoğu'sunda yoğunluk kazanmaktadır. Fakat son yıllarda gerçekleşen terörist saldırıları dikkate alırsak böyle bir sınır çizmenin anlamsız olacağı görülecektir. 10 Ekim 2015 tarihinde Ankara'da yaşanan katliam maalesef bu duruma en yakın örnektir. Söz konusu katliamda üç saniye arayla iki 
patlama olmuş ve patlamada 107 insan hayatını kaybetmiştir. Yine 13 Mart 2016 tarihinde gerçekleşen patlamayla 37 kişi hayatını kaybederken 125 kişi yaralanmıştır.

\section{LITERATÜR TARAMASI}

Terör faaliyetlerinin ekonomik, siyasi, sosyal, kültürel ve psikolojik etkileri ve sonuçları hem Türkiye'de hem de Dünya ülkelerinde birçok akademik çalışmaya konu olmuştur. Terörün niteliğini, yapısını ve etkilerini farklı perspektiflerden anlamaya çalışmak, terörle mücadelede büyük önem arz etmektedir. Bu bağlamda Alp (2013), terörün yatırımlar, turizm, doğrudan yabancı sermaye yatırımları, tüketici davranışları, tüketim ve tasarruflar, menkul kıymet piyasaları, dış ticaret, tarım ve hayvancılık, devlet bütçesi, milli gelir ve ekonomik büyüme üzerine etkilerini geniş çapta incelemiştir.

Alp (2013) yaptığı çalışmada, globalleşme ile beraber finansal piyasaların entegrasyonunun terör gibi ekonomik belirsizlik içeren olayların sonuçlarının, ulusal çapta sonuçlar doğuracağını ifade etmiştir. Terörün ekonomik ve sosyal yönden yıkıcı sonuçlar doğurmasının uluslararası finansal sistemin işleyişini zedeleyeceğini ve ulusal ekonomik dengeleri de bozabileceğini belirtmiştir. Terörün, araştırmacının belirlediği değişkenlere olan etkileri genel olarak şöyledir: Terörle mücadele için gerçekleştirilen harcamalar, işlem maliyetlerini yükseltmekte, bu durum yatırımların azalmasına ve kamu harcamalarında artışa neden olmaktadır. Terörün yarattığı risk ve belirsizlik ortamı istihdam üzerinde negatif yönde etki yaratmaktadır. Terör faaliyetleri özellikle turizm sektörünü etkilemekte ve turizm sektöründen elde edilen gelirleri baltalamaktadır. Tarım ve hayvancılıkla uğraşan bölge halkı da terörden doğrudan etkilenmekte ve bu durum yeni istihdam arayışı sebebiyle iç göçe ve beraberinde birçok sosyal soruna neden olmaktadır. Terör olayları sebebiyle gider kalemlerinde artış, gelir kalemlerinde ise azalış olması devlet bütçesini olumsuz yönde etkilemekte, yabancı sermaye yatırımları ve menkul kıymet piyasaları da terörün yıkıcı etkilerinden nasibini almakta ve tüm bu nedenlerden ötürü ülkede ekonomik büyüme yavaşlamaktadır.

Akıncı vd. (2014), panel iki aşamalı en küçük kareler yöntemini kullanarak 2002- 2011 dönemi itibariyle gelişmiş, gelişmekte olan ve az gelişmiş ülkeler için terörizmin, enflasyon ve ekonomik büyüme üzerindeki etkilerini incelemişlerdir. Yazarlar yaptıkları çalışmada, her üç ülke grubunda terörizmin, enflasyon ve ekonomik büyüme üzerinde negatif yönlü etkiler yarattığı sonucuna ulaşmışlardır.

Akıncı, G. Akıncı ve Yılmaz (2015), terörizmin, doğrudan dış yatırımlar ve portföy yatırımları üzerindeki etkilerini araştırdıkları çalışmada, terörizmin doğrudan ve dolaylı yatırımlar üzerinde yarattığı negatif etkilerin, belirtilen ülkelerce alınan dış yardımlar kanalıyla telafi edilip edilemeyeceğini incelemişlerdir. 67'si gelişmekte olan ve 18'i az gelişmiş olmak üzere toplam 85 ülke için 2005-2011 dönemi itibariyle dengesiz panel veri analizleri kullanılarak yapılan çalışmada, terörizmin doğrudan ve dolaylı yatırımlar üzerinde negatif etki yarattığı ortaya konulmuştur. Dış yardım akımlarının, terörizmin yabancı yatırımlar üzerinde yarattığı olumsuz etkiyi azalttığı ortaya konulmuştur.

Terör faaliyetlerinden doğan belirsizliklerin finansal piyasalara etkilerini, 35 ülke için 2003-2011 dönemi itibariyle Vision of Humanity'den elde edilen küresel terör endeksleri ve Dünya Borsalar Birliği'nden elde edilen yıllık ortalama borsa endeksleri verileri yardımıyla panel veri modelleri kullanarak inceleyen Ağırman, Özcan ve Yılmaz (2014), terörist faaliyetlerin hisse senedi piyasaları üzerine gerçekleşen kısa vadeli olumsuz etkilerinin uzun dönemde piyasa mekanizması tarafından düzeltildiği sonuca ulaşmışlardır.

Panel veri analizlerini kullanarak Türkiye, Mısır ve Suudi Arabistan için 1996-2010 yılları itibariyle ihracat, ithalat, ekonomik büyüme, turizm, doğrudan yabanc1 yatırımlar, işsizlik 
ve kişi başına milli gelir gibi ekonomik değişkenlere ait veriler yardımıyla Ortadoğu'da yaşanan terör olaylarının seçilmiş ülke ekonomileri üzerindeki etkilerini inceleyen Altay, Ekinci ve Peçe (2013), turizm başta olmak üzere terörün analize tabi tutulan tüm ekonomik değişkenler üzerinde olumsuz etki yarattı̆̆ını ortaya koymuşlardır.

Yıldız, S. Yıldız ve Aytemiz (2015), Doğu ve Güneydoğu Anadolu Bölgelerini ele alarak, Türkiye'de kara turizm uygulamaları ve mevcut potansiyelini incelemeye yönelik yaptıkları çalışmada, bu bölgelerde yaşanan terör olaylarının, atılan demokratikleşme adımlarıyla birlikte bitmesinin ardından, bölgenin kara turizm faaliyetlerine açılmasına yönelik gelişimi incelemişlerdir.

Yeşiltaş, Öztürk ve Yeşilmen (2008), terörizm faaliyetlerinin Dünya ve Türkiye perspektifinde turizmle olan ilişkisi ve turizme olan etkilerini ayrıntılı olarak çözüm önerileri perspektifinde inceleyerek literatüre katkıda bulunmuşlardır.

Zaman serileri analizleri ARIMA modelini kullanarak 1984-2001 yılları itibariyle Türkiye'de ekonomik açıdan önemli bir gösterge olan turizm sektörünün, terör faaliyetlerinden etkilenme mekanizmasını inceleyen Emsen ve Değer (2004), turizm ve terörizm arasında ters yönlü bir ilişkinin olduğu ve Türkiye için önemi giderek artan turizm gelirlerinin terör olgusundan tecrit edilemeyeceği sonucuna varmışlardır.

Sezgin, Ş.Sezgin ve Gündüz (2008), silahlı çatışmanın ekonomik sonuçlarını Güneydoğu Anadolu Bölgesini Türkiye'de diğer bölgelerle karşılaştırarak analiz ettikleri çalışmada, ekonomik büyümenin, Güneydoğu Anadolu Bölgesi'nde diğer bölgelere göre daha yavaş olduğu ve bölgeler arasında ıraksamaya neden olduğu sonucuna ulaşmışlardır.

Bashir, Inam-ul-Hag ve Gillani (2013), GARCH ve GARCH EVI modellerini kullanarak 2005-2010 dönemi itibariyle yaşanan terör faaliyetlerinin finansal piyasalara etkilerini Pakistan Karaçi Borsası'nı baz alarak incelemişlerdir ve araştırma bulgularına göre KSE 100 endeksi ile terör faaliyetleri arasında negatif yönlü bir ilişki olduğunu tespit etmişlerdir.

Aslam ve Kang (2013), olay çalışması yöntemini kullanarak Pakistan'da 2000 ve 2001 yılları arasında gerçekleşen 470 terör faaliyetlerinin KSE Borsasına etkilerini ele almışlardır. Çalışmada, federal olarak yönetilen kabile alanlarında gerçekleşen terör faaliyetlerinin Borsada pozitif yönde bir etki yaratırken, şehirlerde meydana gelen terör faaliyetlerinin ise negatif yönde bir etki yarattığı saptanmıştır. Ayrıca kaybedilen insan hayatları ile KSE 100 Endeksi arasında negatif yönlü bir ilişki olduğu tespit edilmiştir ve farklı şekillerdeki saldırıların finansal piyasalar üzerinde farklı etkiler yaratacağı bulgusuna ulaşmışlardır.

Abadie ve Gardeazabal (2003), Bask bölgesinde bulunan ETA terör örgütünün gerçekleştirdiği terör faaliyetleri esas alarak, çatışmaların ekonomik etkilerini incelemek üzere ampirik bir çalışma yapmışlardır. Araştırmada sonuç olarak, 1960'ların sonunda terörün patlak vermesinden sonra Bask Bölgesinde, terörizmin olmadığı sentetik kontrol bölgesine göre kişi başına düşen milli gelirin \%10'a düştüğü bulgusuna ulaşılmıştır. Ek olarak 1998-1999 tarihleri arasında yapılan ateşkes örneği kullanılmış ve ateşkesin güvenirlik kazanması durumunda Bask Bölgesindeki şirketlerin hisse senetleri ile şirketler için önem arz eden faktörlerin pozitif yönde bir eğilim gösterdiği, ateşkesin sona ermesiyle ise negatif yönlü bir eğilim gösterdiği tespit edilmiştir. Bir diğer çalışmalarında Abadie ve Gardeazabal (2008), terörizmin entegre bir dünya ekonomisinde doğrudan yabancı sermaye yatırımları üzerindeki etkilerini 110 ülkeyi dikkate alarak yatay kesit analizi yardımıyla incelemişlerdir. Terörizmin genel olarak ekonomik riskin küçük bir kısmını temsil etse bile, ülkeler arasında üretken sermayenin tahsisinde büyük bir etkiye sebep olduğu sonucuna ulaşmışlardır.

Terör faaliyetlerinin hisse senedi fiyatlarına etkilerini olay çalışması yöntemi yardımıyla inceleyen Karolyi ve Martell (2010), 1995 ve 2002 yılları arasında gerçekleşen 75 terör 
saldırısını ele almışlardır. Çalışmada, saldırının gerçekleştiği gün, hisse senedi fiyatlarında $0,83 \%$ oranında bir değer kaybı yaşandığı ve ortalama bir firmanın 401 milyon dolar zarara uğradığı sonucuna ulaşılmıştır. Şirket yöneticilerinin kaçırılması gibi insan sermayesi kayıplarının, fiziksel kayıplara oranla hisse senetleri fiyatları üzerinde daha fazla etkili olduğu tespit edilmiştir.

\section{METODOLOJİ}

Zaman serisi ekonometrisi yaklaşımında ele alınan modellerde değişkenlerin, durağan yani, ortalama ve varyanslarının zamanla değişmediği varsayılmaktadır (Sevüktekin ve Nargeleçekenler, 2005: 37). Zaman serilerinin durağan olmas1; zaman içinde varyansın ve ortalamanın sabit olması ve gecikmeli iki zaman periyodundaki değişkenlerin kovaryansının değişkenler arasındaki gecikmeye bağlı olup zamandan bağımsız olması anlamına gelmektedir (Gujarati, 1995: 712). Fakat uygulamada karşılaşılan ekonomik zaman serilerinin çoğu durağan değildir. İlgilenilen seri orijinal değerlerinde durağan değilse ve durağanlığ unsuru ise, serinin uygun $\mathrm{d}$ dereceden ( $\mathrm{d}=1,2$ için) sıralı farkları alınır (Ö̈zer ve Türkyılmaz, 2004:12).

Zaman serisi ekonometrisinde sahte regresyona neden olacak durağan olmama durumlarından kaçınmak amacıyla, incelediğimiz zaman serilerinin durağanlık açısından test edilmesi gerekmektedir (Dokuz Eylül Üniversitesi [DEÜ], 2005:1). Birinci aşamada serilerin bütünleşme dereceleri yani durağanlığının sağlanması için kaçıncı farkının alınması gerektiği belirlenmelidir. Değişkenlerin durağanlığını belirlemek amacıyla çok sayıda birim kök testi vardır. En yaygın kullanılanları Augmented Dickey-Fuller (ADF), Philips-Peron (PP), Elliot, Rothenberg, and Stock (ERS), Ng and Perron (NP), ve Kwiatkowski, Phillips, Schmidt ve Shin (KPSS)'dir. Ancak Perron'nun 1989 yılındaki çalışmasında vurgulandığı gibi seride yapısal kırılma varsa yukarıda söz ettiğimiz testlerin sapmalı sonuçlar vereceği belirtilmektedir. Bu durumda yapısal kırılmalı birim kök testi uygulanmalıdır (Eviews Help, Erişim Tarihi: 6.1.2016).

Perron (1989), ADF testine alternatif, yapısal kırılmaların varlığı durumunda önerdiği yeni teste göre, ADF testinin birim kök hipotezini reddetmekte başarısız olmasına karşın, serinin deterministik trend fonksiyonu etrafında durağan olabileceği iddia edilmiştir. Aynı zamanda, bu çalışmada, serinin trend fonksiyonunda meydana gelen kırılma zamanı dışsal olarak belirlenmiş, yani önsel bilgi kullanılmıştır (1929 Büyük Buhranı ve 1973 Petrol Krizi). Çalışmada, yapısal değişim ya da kırılma zamanı $T_{B}$ olarak alınmış $\left(1<T_{B<\mathrm{T})}\right.$ ve üç farklı fonksiyonla ilgili birim kök testi kullanılmıştır. Bu yaklaşım $T_{B}$ anında bir tek zaman değişikliğine izin verilerek genelleştirilmektedir. Boş Hipotez "verilen $\left\{y_{t}\right\}_{1}^{T}$ serileri bir kırılma zamanı ile bir birim köke sahiptir" şeklindedir (Uğurlu, 2015).

Perron (1997), Perron (1989) çalışmasının yeniden ele alındığı bir çalışmadır. Bu çalışma, bir öncekinin aksine, zamandaki olası değişiklik A Priori olarak saptanmamıştır. Çalışmada, trend durağan alternatif hipoteze karşı, birim kök Boş Hipotezini test etmek için Perron (1989)'da olduğu gibi üç farkl1 model önerilmiştir (Uğurlu, 2015).

Model A: Innovational Outlier Model

$$
y_{t}=\mu+\theta D U_{t}+\beta t+\delta D\left(T_{B}\right)_{t}+\alpha y_{t-1}+\sum_{i=1}^{k} c_{i} \Delta y_{t-i}+\varepsilon_{t}
$$




$$
D U_{t}=\left\{\begin{array}{l}
1, t>T_{B} \\
0, d . h .
\end{array} \quad D\left(T_{B}\right)_{t}=\left\{\begin{array}{l}
1, t=T_{B}+1 \\
0, d . h .
\end{array}\right.\right.
$$

Bu model, yokluk ve alternatif hipotezler altında, trend fonksiyonunun sabitinde sadece bir defalık değişime izin vermektedir. Ayrıca bu değişimin, yavaş yavaş ve gürültü fonksiyonunun korelasyon yapısına bağlı olarak meydana geldiği varsayılmaktadır. Bu model için birim kök testi yukarıda verilen regresyonda $\alpha=1$ kısıtlamasının testi için t istatistiği kullanılarak yerine getirilir.

Model (B) : Additive Outlier Model

Burada değişim ani oluşmaktadır ve bu durum iki adımda izlenebilir (Yurdakul, 2000: 27).

\section{Adım:}

$$
\begin{aligned}
& y_{t}=\mu+\beta t+\delta D T_{t}^{*}+e_{t} \\
& D T_{t}^{*}=\left\{\begin{array}{l}
t-T_{B}, t>T_{B} \\
0, d . h .
\end{array}\right.
\end{aligned}
$$

Denkleme KEKK yöntemi uygulanarak $e_{t}$ 'ler bulunur.

\section{Adım:}

$$
e_{t}=\alpha e_{t-1}+\sum_{i=1}^{k} \lambda_{i} \Delta y_{t-i}+e_{t}
$$

Bu modelde birim kök testi, denklemde $\alpha=1$ kısıtlamasının t istatistikleri kullanılarak gerçekleştirilir.

Model (C) : Her iki etkiyi de içerir (Yurdakul, 2000: 27).

$$
\begin{gathered}
y_{t}=\mu+\theta D U_{t}+\beta t+\delta D T_{t}+\delta D\left(T_{B}\right)_{t}+\alpha y_{t-1}+\sum_{i=1}^{k} \lambda_{i} \Delta y_{t-i}+e_{t} \\
D T_{t}=\left\{\begin{array}{l}
t, t>T_{B} \\
0, d . h .
\end{array}\right.
\end{gathered}
$$

Bu model, $T_{B}$ kırılma anında, trend fonksiyonunun sabitinde ve eğiminde bir değişime müsaade etmektedir. Test, yukarıda verilen regresyonda $\alpha=1$ Boş Hipotez için t istatistikleri kullanılarak yapılır (Uğurlu, 2015).

Üç model altında, kırılma zamanı $T_{B}$ ve gecikme uzunluğu k ile birlikte, $\alpha=1$ Boş Hipotezini test etmek için kullanılan $\mathrm{t}$ istatistikleri, ${ }_{\alpha^{*}}\left(i, T_{B}, k\right)(i=1,2,3)$ olarak gösterilir. Bu regresyonlarda $T_{B}$ ve k değerleri bilinmemekle birlikte içsel olarak tahmin edilmektedir (Uğurlu, 2015).

Durağanlık, bir zaman serisi modeli açısından olmazsa olmaz bir önkoşul olarak değerlendirildiğinden, durağanlık şartı sağlandıktan sonra ancak kullanılacak analizin uygulamasına geçilebilmektedir. Daha sonraki aşamada durağanlığı sağlanan değişkenlerin 
modele ne şekilde ekleneceği konusu da teoride oldukça önemli bir noktaya işaret etmektedir. Engle 1982 ve 1983 'te yaptığı çalışmalarda, İngiltere enflasyon verilerini inceleyerek hata terimlerinin varyansının sabit olmadığını ispat etmiştir. Engle tarafından yapılan bu çalışma, Otoregresif Koşullu Değişen Varyans (ARCH) ismi ile literatüre girmiştir (Güvenek ve Alptekin, 2009: 299). Bu modelde koşullu varyans, hata terimlerinin mutlak ya da kare değeri ve koşullu gecikmeli standart sapmalar ya da varyanslara bağlıdır (Gürsakal, 2009: 322). Sabit varyans varsayımının geçersiz olduğu durumda, koşullu varyansın bir AR(p) modeli ile tahmini basit bir şekilde yapilabilir (Enders, 2004: 114).

ARCH (q) genel modeli;

$$
h_{t}=\alpha_{0}+\sum_{i=1}^{q} \alpha_{i} u^{2}{ }_{t-1}
$$

şeklinde yazılabilir. Hata terimleri varyansında ardışı bağımlılık yoksa $\alpha_{1}=\alpha_{2}=\ldots . .=\alpha_{q}=0$, olmaktadır. Bu durumda hesaplanan varyans basitçe $\alpha_{0}$, a eşit olur. Böylece hata terimleri basitçe sabit varyansa sahip olabilmektedir. Engle tarafindan ifade edilen aşağıdaki denklemin hesaplanması ile sıfır hipotezi kolayca sınanabilmektedir;

$$
u_{t}^{2}=\beta_{0}+\beta_{1} u_{t-1}^{2}+\beta_{2} u_{t-2}^{2}+\ldots . .+\beta_{q} u_{t-q}^{2}+v_{t}
$$

Denklemde ifade edilen eşitlik, otoregresif koşullu değişen varyans olarak bilinir. Buradaki $(u)$ terimi koşullu ortalama denkleminden elde edilen hata terimidir. $\mathrm{Bu}$ model de koşullu varyans denkleminin kalıntılarının geçmiş değerlerinin karelerinin bir fonksiyonu olarak tanımlanmaktadır (Güvenek ve Alptekin, 2009: 300).

ARCH modelleri, geleneksel zaman serisi yöntemlerindeki sabit varyans varyansını bir kenara bırakarak varyansın gecikmeli tahmin hatalarının bir fonksiyonu olarak değişmesine izin vermektedir. $\mathrm{Bu}$ nedenle $\mathrm{ARCH}$ modelleri tahmin sürecindeki değişen varyansı regresyonla birleştirmeye uygundur. ARCH modelinde tahmin hatalarının karakteristik davranışlarının, regresyon artıklarına dayandığı varsayılmaktadır. Bu varsayım sonucunda regresyon artıkları da otokorelasyonlu olacaktır (Engle, 2001:157).

ARCH modelleri için en küçük kareler artıklarını kullanarak Lagrange Çarpanı (LM) testi ile ARCH etkisi test edilebilir (Güvenek ve Alptekin, 2009: 300).

$$
h_{t}=\alpha_{0}+\alpha_{1} u^{2}{ }_{t-1}+\alpha_{2} u^{2}{ }_{t-2}+\ldots \ldots .+\alpha_{q} u^{2}{ }_{t-q}
$$

$\mathrm{Bu}$ amaçla yardımcı regresyon olarak da bilinen (q) gecikme uzunluğuna sahip koşullu varyans modelinde hataları ARCH etkisine sahip olduğunu savunan ve savunmayan hipotezler aşağı da verilmektedir;

$$
\begin{gathered}
H_{0}=\alpha_{1}=\alpha_{2}=\ldots . .=\alpha_{q} \\
H_{A}=\text { enazbir }_{i}>0(i=1,2, \ldots, q)
\end{gathered}
$$

Hipotezlerde görüldüğü gibi sıfır hipotezde $\mathrm{ARCH}$ etkisi olduğu reddedilirken, alternatif hipotezde ARCH etkisinin olduğu ileri sürülmektedir. Bununla ilgili olarak test istatistiği ise LM $=\mathrm{T} *\left(R^{2}\right)$ şeklinde olmaktadır (Güvenek ve Alptekin, 2009: 300).

Engle'in Lagrange Çarpanı testi, $T R^{2}$ test istatistiğine dayanır. Buradaki $R^{2}, u^{2}{ }_{t}{ }^{\prime}$ nin bir sabit üzerine ve $u^{2}{ }_{t-1}, \ldots, u_{t-q}^{2}$ üzerine regresyonundan hesaplanmaktadır. T farkı alınmış 
örneklem mevcududur. ARCH etkilerinin olmadığı sıfır hipotezi altında test istatistiği q serbestlik derecesi ile bir $\chi^{2}$ dağılımı gösterir (Bollerslev vd., 1994).

Bir Lagrange testi olan ARCH LM testi, modelin hata terimlerinde otoregresif koşullu değişen varyans etkilerinin bulunup bulunmadığına ilişkin olarak geliştirilmiştir. ARCH etkisi zaman serilerinde göz ardı edildiğinde tahminlerin etkinliği azalmaktadır (Güvenek ve Alptekin, 2009:301).

ARCH modelinin uygulamasında, nispi olarak uzun gecikmeler kullanılması ve sabit gecikme yapısının önerilmesi nedeniyle, koşullu varyans denklemindeki parametrelere bazı kısıtlamalar konulmuştur. $\mathrm{Bu}$ kısıtlamaların sağlanamaması ve negatif varyanslı parametre tahminlerine ulaşılması sakıncasını gidermek amacıyla Bollerslev (1986), ARCH modelini genişleterek, hem daha fazla geçmiş bilgiye dayanan hem de daha esnek bir gecikme yapısına sahip olan bir model geliştirmiştir. Söz konusu modele genelleştirilmiş ARCH (GARCH) adını vermiştir (Bollerslev, 2000: 42- 60).

GARCH modelleri, koşullu varyansın hata teriminin gecikmeli değerlerine ilave olarak, kendi gecikmeli değerlerine de bağlı olduğu oynaklık modelidir. Bu model; geçmiş kalıntı karelerinin ağırlıklandırılmış ortalamasıdır, fakat asla bütünüyle sıfıra gitmeyen azalan ağırlıklara sahiptir (Engle, 2001:159).

ARCH modelinden hareketle Bollerslev (1986)'in önerdiği GARCH(p,q) modeli;

$$
\begin{aligned}
& u_{t}=\eta_{t} \sqrt{h_{t}} \\
& h_{t}=\alpha_{0}+\sum_{i=1}^{p} \alpha_{i} u_{t-1}^{2}+\sum_{i=p}^{q} \beta_{i} h_{t-i}
\end{aligned}
$$

Burada, $h_{t}>0$ için, $\alpha_{0}>0, \alpha_{i} \geq 0, \beta_{i} \geq 0,{ }_{(\mathrm{i}=1,2, \ldots, \mathrm{p})}$ ve ${ }^{h_{t}}$ ortalaması sıfır varyans1 olan bir olan tesadüfi değişkendir (Güvenek ve Alptekin, 2009:301). GARCH yapısının varlığı yine ARCH yapısının teşhisi gibi aynı mantıktaki LM testi ile test edilebilir.

ARCH modellerinin Bollerslev (1986) tarafindan GARCH modeline genelleştirilmesinin ardından daha sonraki dönemde, birinci ve daha yüksek momentlerdeki doğrusal ve doğrusal olmayan bağımlılıkların modellenmesi için GJR-GARCH, EGARCH, PARCH, IGARCH, CGARCH ve GARCH-M gibi versiyonları geliştirilmiştir (Mazıbaş, 2015: 5). Bu çalışmada GARCH, EGARCH, PGARCH ve CGARCH modeli kullanılmıştır.

GARCH modeli başarılı bir şekilde finansal varlık getirilerinde gözlemlenen ampirik bulgular olan kalın kuyruk ve oynaklık kümelenmesi olgularını yakalamaktadır. Bununla birlikte, GARCH modelinde de koşulsuz varyans gecikmeli hata terimlerinin işaretlerinden bağımsız olarak sadece büyüklüklerinin bir fonksiyonu olarak tanımlandığından, GARCH süreci varyans yapısındaki asimetriyi yakalamakta başarısız kalmaktadır. Nelson (1991) oynaklık yapısındaki asimetriyi hesaba katacak şekilde, koşullu varyansın, gecikmeli hata terimlerinin hem büyüklükleri hem de işaretleri dikkate alınarak modellendiği Üssel GARCH (EGARCH) modelini geliştirmiştir (Songül, 2010: 18).

PARCH modelinde, standart sapmanın güç parametresi olan $\gamma$ tahmin edilebilmekte ve tercihe bağlı olarak süreçteki asimetriyi yakalamak adına $\delta$ parametresi modele dâhil edilmektedir. $\delta$ parametresinin istatistikî olarak anlamlı çıkması, süreçteki asimetriye işaret etmektedir (Songül, 2010: 19). 7).

Doğrusal olmayan kısıtlanmış GARCH $(2,2)$ modeli aşağıdaki gibidir (Mazıbaş, 2015: 


$$
\sigma_{t}^{2}=(1-\alpha-\beta)(1-\rho) \omega+(\alpha+\phi) u_{t-1}^{2}-(\alpha \rho+(\alpha+\beta) \phi) u_{t-2}^{2}+(\beta-\phi) \sigma_{t-1}^{2}-(\beta \rho-(\alpha+\beta) \phi) \sigma_{t-2}^{2}
$$

Modelin koşullu varyans denkleminin geçici ve kalıcı bölümlerine dışsal değişkenler eklenebilmektedir. Geçici bölümü gösteren denkleme eklenen değişkenler volatilitedeki kısa dönemli hareketler üzerinde etkide bulunurken, kalıcı etkileri gösteren denkleme eklenecek değişkenler volatilitenin uzun dönemdeki seviyesine etkide bulunacaktır (Mazıbaş, 2015: 7).

Asimetrik Component GARCH modeli, GARCH $(2,2)$ modeli ile GJR-GARCH modelinin bir araya getirilmesinden oluşmaktadır. GARCH $(2,2)$ modelinin kalıcı etkileri gösteren bölümünde herhangi bir değişiklik yapılmazken, GJR modelinden alınan asimetrik terimler modelin geçici etkileri gösteren bölümüne ilave edilmektedir (Mazıbaş, 2015: 7).

$$
\begin{gathered}
y_{t}=x_{t}^{\prime} \pi+u_{t} \\
q_{t}=\omega+\rho\left(q_{t-1}-\omega\right)+\phi\left(u_{t-1}^{2}-\sigma_{t-1}^{2}\right)+\theta_{1} z_{1 t} \\
\sigma_{t}^{2}-q_{t}=\alpha\left(u_{t-1}^{2}-q_{t-1}\right)+\gamma\left(u_{t-1}^{2}-q_{t-1}\right) d_{t-1}+\beta\left(\sigma_{t-1}^{2}-q_{t-1}\right)+\theta_{2} z_{2 t}
\end{gathered}
$$

(18)'da yer alan modelde, $z$, denklemlere ilave edilebilen dişsal değişkenleri, $d$ ise negatif şokları gösteren kukla değişkeni göstermektedir. Negatif şokları gösteren değişkenin parametresi olan $\gamma$ 'nin aldığı değer kaldıraç etkisinin mevcut olup olmadığını göstermektedir: $\gamma>0$ ise koşullu varyans modelinde geçici kaldıraç etkisi mevcuttur (Mazıbaş, 2015:8).

\section{VERİ VE BULGULAR}

Çalışmada kullanılan BİST 100 Endeksi kapanış verileri, DATASTREAM veri sisteminden aylık olarak 1990-2015 dönemlerini kapsayacak şekilde temin edilmiştir. BİST 100 Endeksindeki hisse senetleri getirilerinin zaman içinde sergilediği performansa Grafik 1 ve Grafik 2 arac1lığıla bakmak gerekirse;

. $\mathrm{XU100}$

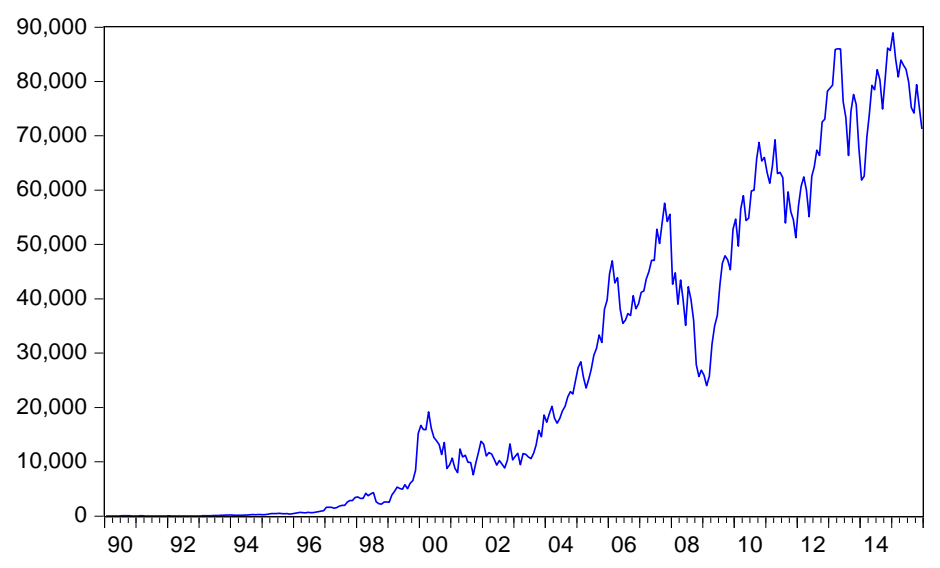

Grafik 1: BEPG 1990:1-2015: 12 Dönemindeki Orijinal Değerleri 
LINDEX

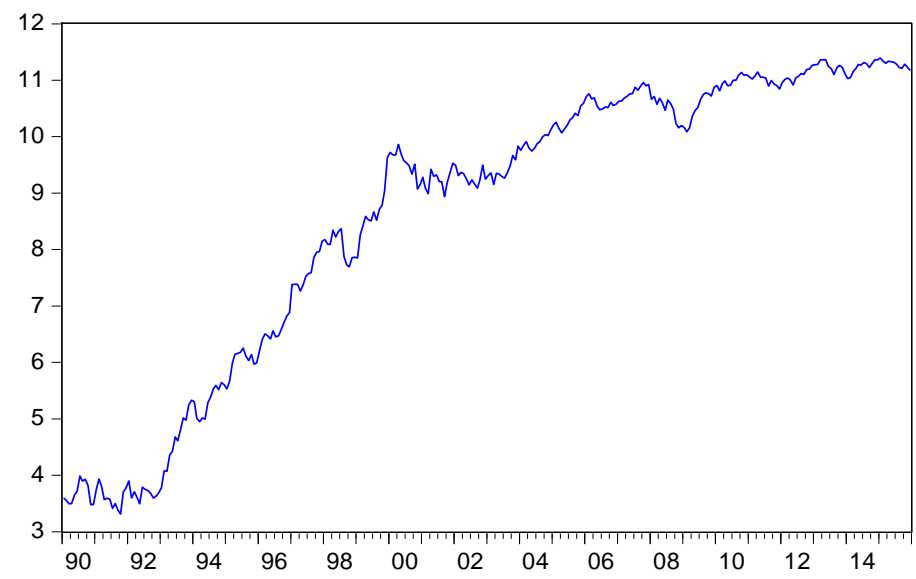

Grafik 2: BEPG 1990:1-2015: 12 Dönemindeki Logaritmik Değerleri

BEPG ile ilgili özelliklerin belirlenmesi için ilk olarak BEPG serisinin karakteristik grafiğini değerlendirmek yerinde olacaktır. Grafik 1'de BEPG serisinin zaman içindeki seyri, Grafik 2'de ise BEPG logaritmik değerleri gösterilmektedir. Grafiklerden de açıça görülebileceği üzere hem orijinal hem de logaritmik değerlerde kırılmalar vardır ve trendli bir yap1 mevcuttur. 1993 yılına kadar kayda değer ölçüde iniş ve çıkışlar olmamakla beraber 1993 yılından sonra seri yükseliş trendine geçmiştir. Bu durum serinin durağanlığı hakkında fikir vermektedir. Durağanlık zaman serileri için olmazsa olmaz bir ön koşul olduğundan serinin durağanlığı yapısal kırılmalı birim kök testi yöntemi ile test edilecektir.

Borsa endeksi piyasa getirilerinin (BEPG) birim kök içerip içermediğine yönelik olarak yapılan Yapısal Kırılmalı Birim Kök Testi sonuçları Tablo 1'de verilmektedir.

Tablo 1: Borsa Endeksi Piyasa Getirilerinin Orijinal Seviyesinin YKBK Test İstatistiği

\begin{tabular}{|c|c|c|c|c|}
\hline & & & & Prob. \\
\hline \multirow{3}{*}{$\begin{array}{l}\text { Yapısal } \\
\text { Kırılmalı } \\
\text { Birim Kök } \\
\text { Testi (YKBK) }\end{array}$} & \multirow{3}{*}{-4.587327} & $\% 1$ & -5.719131 & \multirow{3}{*}{0.1986} \\
\hline & & $\% 5$ & -5.175710 & \\
\hline & & $\% 10$ & -4.893950 & \\
\hline
\end{tabular}


Dickey-Fuller t-statistics

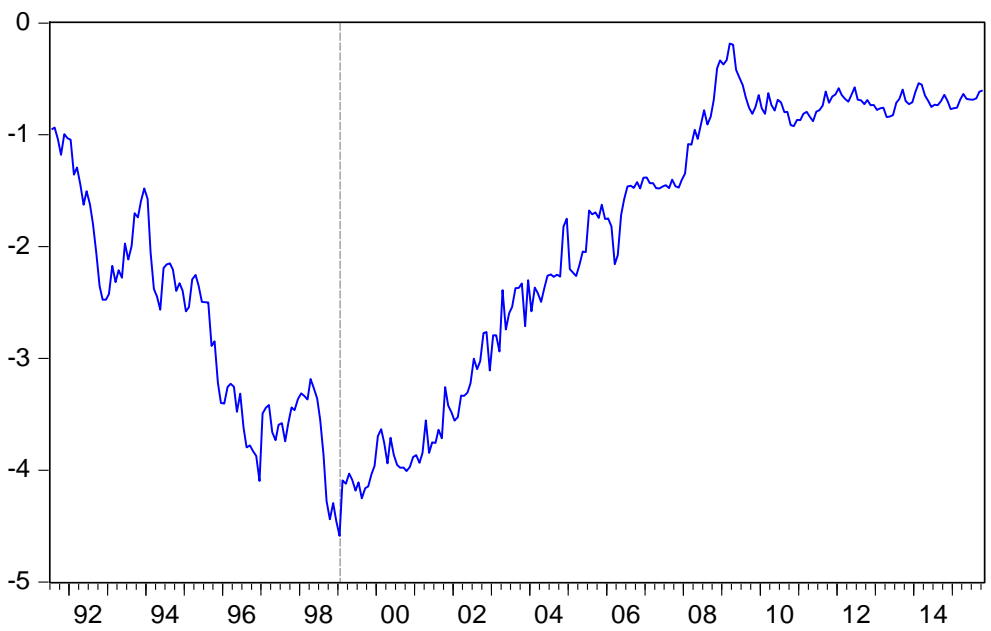

Grafik 3: Borsa Endeksi Piyasa Getirilerinin Orijinal seviyesinin YKBK Test İstatistiği

Tablo 1'den de görüleceği üzere YKBK Test İstatistĭgi $-4.587327, \%$ 1, \% 5 ve \% 10 anlamlılık düzeylerindeki McKinnon kritik değerlerinden büyük olduğu için ve olasıllk değerinin 0,05 'ten büyük olduğu için sıfır hipotezi kabul edilir, yani borsa endeks değerinin orijinal düzeyde durağan olmadığı yönünde karar verilmektedir. Dolayısıyla ortalama eşitliğini belirlemek için piyasa getirilerini yani borsa endeks değerlerinin birinci farkını alarak serinin durağanlığı yeniden test edilmektedir;

\section{Tablo 2: Borsa Endeksi Piyasa Getirilerinin Orijinal Seviyesinin YKBK Test İstatistiği}

\begin{tabular}{|c|c|c|c|c|}
\hline & & & & Prob. \\
\hline \multirow{3}{*}{$\begin{array}{l}\text { Yapısal } \\
\text { Kırılmalı Birim } \\
\text { Kök Test } \\
\text { İstatistiği }\end{array}$} & \multirow{3}{*}{-10.73457} & $\% 1$ & -5.719131 & \multirow{3}{*}{$<0.01$} \\
\hline & & $\% 5$ & -5.175710 & \\
\hline & & $\% 10$ & -4.893950 & \\
\hline
\end{tabular}

Birinci dereceden farkı alınmış D(BEPG) serisinin; YKBK Test İstatistiği -10,73457, \% $1, \% 5$ ve $\% 10$ anlamlılık düzeylerindeki McKinnon kritik değerlerinden mutlak olarak büyük olduğu için sıfır hipotezi reddedilir, yani BEPG serisinin birinci farkı alındığında BEPG serisinin durağan olduğu yönünde karar verilmektedir.

Birinci farkı alınmış D(BEPG) serisinin durağan olduğunu Grafik 4’ten de açıç̧a görmek mümkündür. 
Dickey-Fuller t-statistics

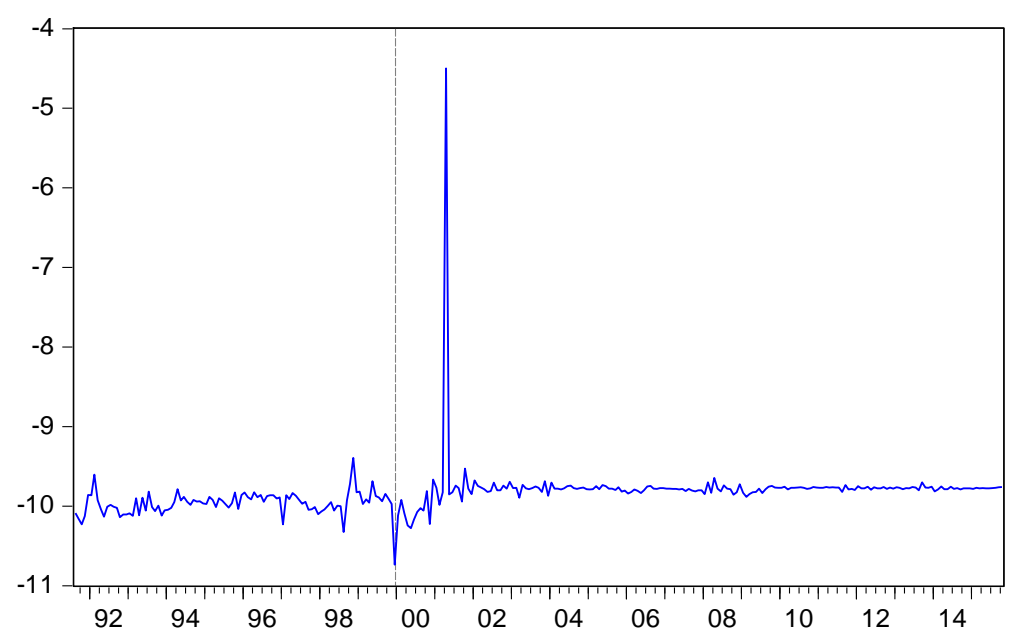

Grafik 4: Birinci Farkı Alınmış D(BEPG) Serisinin Grafiği

Yapısal kırılmalı birim kök testi sonuçlarına göre borsa endeksi piyasa getirilerinin orijinal düzeyinde durağan değilken logaritmik değerlerinin birinci farkında durağandır. Uygun ortalama eşitliğinin bulunması için ARMA maksimum olasılık modellemesi yapılmıştır. Buna göre tahmin edilen ARMA modeli şu şekilde olmaktadır;

Tablo 3: BEPG Serisine İlişkin Olarak Tahmin Edilen ARMA Modeli

\begin{tabular}{lllll}
\hline Değişken & Katsayı & Standart Hata & T-İstatistiği & Prob. \\
\hline $\mathbf{C}$ & 0.024108 & 0.008049 & 2.995227 & 0.0030 \\
$\mathbf{A R}(\mathbf{1})$ & 1.395523 & 0.018940 & 73.68010 & 0.0000 \\
$\mathbf{A R}(\mathbf{2})$ & -0.971428 & 0.018084 & -53.71621 & 0.0000 \\
$\mathbf{M A}(\mathbf{1})$ & -1.355981 & 0.021847 & -62.06730 & 0.0000 \\
$\mathbf{M A}(2)$ & 0.972303 & 0.023151 & 41.99865 & 0.0000 \\
\hline
\end{tabular}

Tablo 3'ten görüleceği gibi en uygun ortalama eşitliği AR(2) ve MA(2) olarak bulunmuştur. $\mathrm{Bu}$ aşamadan sonra bu ortalama eşitliğinde anlamlı ARCH etkisi olup olmadığ 1 ARCH LM testi ile sinanacaktır. 
Tablo 4: ARCH LM Test (12)

\begin{tabular}{cccc}
\hline F-statistic & Obs*R-squared & Prob. F(12,285) & $\begin{array}{c}\text { Prob. Chi } \\
\text { Square(12) }\end{array}$ \\
\hline 3.456044 & 37.85560 & 0.0001 & 0.0002 \\
\hline
\end{tabular}

$\mathrm{LM}=\mathrm{T} *\left(R^{2}\right)=298 * 0,127032=37.85560$ ve Prob. Chi Square(12) değeri 0,05 olas1lık değerinin altında olduğu için yapılan ARCH LM testine göre bulunan ortalama eşitliğinde anlamlı ARCH etkisi olduğu görülmektedir. Bu nedenle sonraki aşamada borsa getirisinin koşullu varyansını diğer bir deyişle oynaklığını hesaplayacağımız uygun GARCH modelini bulunacaktır. $\mathrm{Bu}$ amaçla GARCH, EGARCH, PGARCH ve Component GARCH modelleri tahmin edilecektir.

Tablo 5: D(BEPG) Serisinin GARCH, EGARCH, PGARCH ve CGARCH Modellerine İlişkin Varyans Eşitlikleri Sonuçları

\begin{tabular}{lcccc}
\hline & GARCH & EGARCH & PGARCH & CGARCH \\
\hline Log likelihood & 213.9157 & 188.4517 & 216.1915 & 221.4454 \\
Akaike info criterion & -1.328488 & -1.157753 & -1.330268 & -1.357712 \\
Schwarz criterion & -1.232061 & -1.049272 & -1.209733 & -1.225124 \\
Hannan-Quinn Criter & -1.289941 & -1.114387 & -1.282083 & -1.304709 \\
\hline
\end{tabular}

Tablo 5'teki veriler dikkate alındığında CGARCH modeli, en yüksek log likelihood ve en düşük Akaike, Schwarz ve Hannan-Quinn değerlerine sahip olduğu için uygun model olarak seçilmiştir. Component GARCH modeli için tahmin edilen eşitlik aşağıdaki gibidir:

DLINDEX $=0.0093962363586+[\mathrm{AR}(1)=-0.0056913244216, \mathrm{AR}(2)=$ $0.00403548449356, \mathrm{MA}(1)=0.0029874941955, \mathrm{MA}(2)=0.00011501748078, \mathrm{ESTSMPL}=" 1990 \mathrm{M}$ 03 2015M12"]

$\mathrm{Q}=0.0165644675405+0.996954254867 *(\mathrm{Q}(-1)-0.0165644675405)+$ $0.0617085991612 *\left(\operatorname{RESID}(-1)^{\wedge} \mathbf{2}\right.$ - GARCH(-1))

$\mathrm{GARCH}=\mathrm{Q}+(-0.128778867126+0.0169435361644 *(\operatorname{RESID}(-1)<0))^{*}\left(\mathbf{R E S I D}(-\mathbf{1})^{\wedge} \mathbf{2}-\mathrm{Q}(-1)\right)$ $+0.396125138046 *($ GARCH$(-1)-Q(-1))$ 
Component GARCH modelinden elde edilen koşullu varyans serisini kullanarak aşağıdaki piyasa getirileri volatilite grafiği elde edilmiştir.

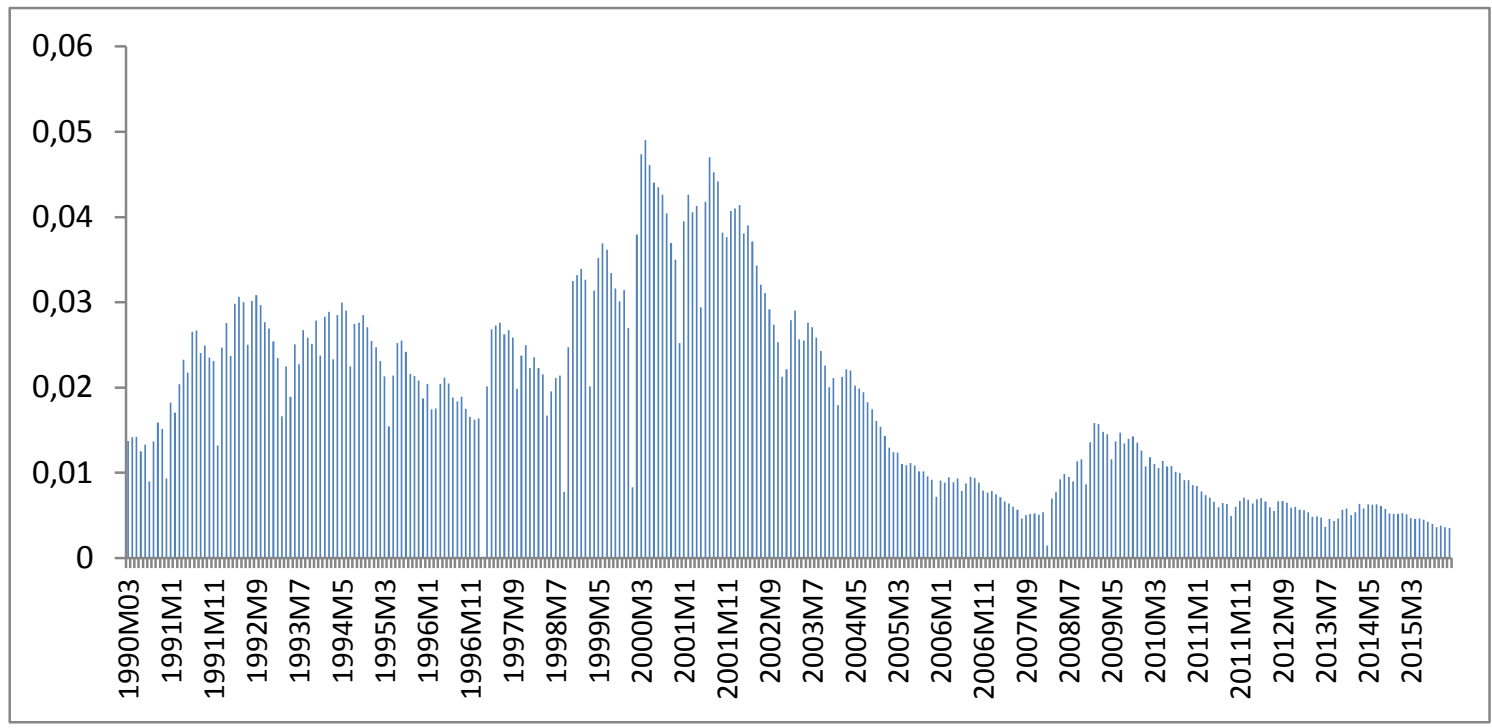

Grafik 5: Component GARCH Modeline Göre Piyasa Getirilerinin Volatilite Grafiğgi

Component GARCH grafiğini elde etmekteki amacımız, volatilitedeki artış veya azalışların ortaya çıktığı tarih itibariyle belirli bir ekonomik, siyasi ya da borsa endeksini etkileyen herhangi bir olayla ilişkisi olup olmadığını belirlemektir. Volatilitedeki belirgin değişmelerin bulunduğu tarihlerde, yurtiçinde veya yurtdışında borsa endeksini etkileyen herhangi bir ekonomik, siyasi ve toplumsal bir gelişme bulunmuyorken, o tarihlerde gerçekleşmiş olan herhangi bir terör olayı bulunuyorsa o halde volatilitedeki değişmelere terör olaylarının neden olduğu sonucuna ulaşılacaktır. Yani bir anlamda olmayana ergi yöntemi kullanılarak terör olaylarının Türkiye'de hisse senedi piyasa getirisi üzerindeki etkilerini belirlenmeye çalışılacaktır.

Çalışmamızın bu bölümünde oynaklıklarda belirgin değişmelerin olduğu tarihlerde meydana gelen siyasi ve iktisadi gelişmelere yer verilmektedir. Aynı zamanda belirlenen tarihler de gerçekleşmiş olan terör faaliyetleri de ele alınmaktadır.

Tablo 6: En Yüksek ve En Düşük Volatilite Meydana Gelen Aylarda Yaşanan Terör Olayları ve Diğer Olaylar

\begin{tabular}{cccc}
\hline TARİ & $\begin{array}{c}\text { VOLATÍLİTE } \\
\text { YÖNÜ }\end{array}$ & TERÖR OLAYLARI & DİĞER OLAYLAR \\
\hline Ağustos 1990 & Düşüş & - & Körfez Savaşı \\
Kasım 1990 & Yükseliş & $\begin{array}{c}\text { Doç.Dr. Bahriye Üçok'a } \\
\text { yönelik terör saldırısı }\end{array}$ & $\begin{array}{c}\text { Dünya petrol fiyatlarında düşüş ve } \\
\text { Türkiye'de turizm krizi }\end{array}$ \\
Aralık 1990 & Düşüş & $\begin{array}{c}\text { Kadıöy'de Devlet } \\
\text { Malzeme Ofisi'nde } \\
\text { bombalı saldırı }\end{array}$ & Türkiye'de özel sektörde grev \\
\hline
\end{tabular}




\begin{tabular}{|c|c|c|c|}
\hline Ocak 1991 & Yükseliş & $\begin{array}{l}\text { Adana'daki ABD } \\
\text { Konsolosluğu ile Türk } \\
\text { Amerikan Kültür } \\
\text { Derneği'ne bombalı } \\
\text { saldırı }\end{array}$ & $\begin{array}{c}\text { Körfez Savaşı'nda olası bir Irak } \\
\text { saldırısına karşı Adana'ya füze } \\
\text { yerleştirilmesi }\end{array}$ \\
\hline Nisan 1991 & Yükseliş & - & $\begin{array}{c}\text { Terörle Mücadele Yasası'nın kabul } \\
\text { edilmesi ve yüksek oranlı KİT } \\
\text { zamlarının yapılması }\end{array}$ \\
\hline $\begin{array}{c}\text { Haziran- } \\
\text { Temmuz } 1991\end{array}$ & Yükseliş & - & 48. Türkiye Hükümeti kurulması \\
\hline Aralık 1991 & Düşüş & $\begin{array}{l}\text { Diyarbakır, Şırnak ve } \\
\text { İstanbul'da terör } \\
\text { saldırısı ve Hürriyet } \\
\text { Gazetesi Ankara } \\
\text { Temsilciliği'nde } \\
\text { bombalı saldırı }\end{array}$ & $\begin{array}{l}\text { Yüzde 9-48 arasında değişen KİT } \\
\text { zamları yürürlüğe girmesi }\end{array}$ \\
\hline $\begin{array}{l}\text { Ocak-Şubat } \\
1992\end{array}$ & Yükseliş & $\begin{array}{c}\text { Galleria , Kapalıçarşı ve } \\
\text { İstanbul Ticaret Odası'a } \\
\text { bombalı saldırı }\end{array}$ & $\begin{array}{l}\text { Vergi affının yasalaşması ve } \\
\text { İpragaz'ın özelleşmesi }\end{array}$ \\
\hline Mart 1992 & Düşüş & Nevruz olayları & Erzincan'da deprem \\
\hline $\begin{array}{l}\text { Mayı-Haziran } \\
1992\end{array}$ & Yükseliş & $\begin{array}{l}\text { Şırnak, Bitlis ve } \\
\text { Silvan'da terör } \\
\text { saldırıları }\end{array}$ & $\begin{array}{c}\text { Türkiye ile Rusya arasında Dostluk ve } \\
\text { İşbirliği Anlaşması'nın imzalaması, } \\
\text { 3. İzmir İktisat Kongresi ve yerel } \\
\text { seçimlerin yapılması }\end{array}$ \\
\hline $\begin{array}{l}\text { Ağustos-Eylül } \\
1992\end{array}$ & Yükseliş & Şırnak terör saldırısı & $\begin{array}{c}\text { Tahtakale'de ABD Dolarında } \\
\text { ve İMKB'de endeksinde artış } \\
\text { CHP'nin tekrar açılması }\end{array}$ \\
\hline Mart 1993 & Düşüş & - & $\begin{array}{c}\text { Avrupa Birliği ile Türkiye arasında } \\
\text { Gümrük Birliği Antlaşması'nın } \\
\text { imzalanması } \\
\text { Abdullah Öcalan tek yanlı ateşkes } \\
\text { yapmışıtır. }\end{array}$ \\
\hline Mayıs 1993 & Düşüş & PKK terör saldırıları & $\begin{array}{c}\text { Süleyman Demirel'in Türkiye'nin } 9 . \\
\text { Cumhurbaşkanı seçilmesi ve PKK ile } \\
\text { ateşkesin sona ermesi }\end{array}$ \\
\hline Haziran 1993 & Yükseliş & $\begin{array}{l}\text { Antalya'da terör } \\
\text { saldırıları }\end{array}$ & Türkiye'de 50. hükümeti kurulması \\
\hline Temmuz 1993 & Düşüş & $\begin{array}{c}\text { Başbağlar ve Sivas } \\
\text { katliamı }\end{array}$ & - \\
\hline Mart 1994 & Düşüş & - & $\begin{array}{c}\text { Yerel seçimler ve ülkeye sıcak para } \\
\text { girişi }\end{array}$ \\
\hline Nisan 1994 & Yükseliş & - & $\begin{array}{l}5 \text { Nisan Ekonomik Önlemler } \\
\text { Paketi uygulamaya konulmas1 }\end{array}$ \\
\hline
\end{tabular}




\begin{tabular}{|c|c|c|c|}
\hline Temmuz 1994 & Düşüş & - & $\begin{array}{l}\text { IMF ile Türkiye arasında stand-by } \\
\text { anlaşması yapılması }\end{array}$ \\
\hline Nisan 1995 & Düşüş & - & $\begin{array}{c}\text { Rauf Denktaş'ın, KKTC } \\
\text { cumhurbaşkanı olması ve Türkiye'de } \\
\text { kamu kesiminde grev }\end{array}$ \\
\hline Aralık 1995 & Düşüş & - & Türkiye genel seçimleri \\
\hline Mart 1996 & Düşüş & - & $\begin{array}{c}\text { ANAYOL Hükümeti'nin kurulması, } \\
\text { Stand-By anlaşması sona ermesi, } \\
\text { enflasyonun yükselmesi }\end{array}$ \\
\hline Şubat 1997 & Düşüş & - & $\begin{array}{c}\text { Cari açık artması, Erbakan hükümeti } \\
\text { ile Ordu sürtüşmesi }\end{array}$ \\
\hline $\begin{array}{l}\text { Ağustos-Eylül } \\
1998\end{array}$ & Düşüş & - & $\begin{array}{l}\text { Rusya krizi, Dünya üretim ve } \\
\text { ticaretinde daralma ve Öcalanın } \\
\text { ateşkes ilan etmesi }\end{array}$ \\
\hline $\begin{array}{l}\text { Ocak-Şubat } \\
1999\end{array}$ & Yükseliş & - & $\begin{array}{l}\text { Öcalanın, Kenya'da yakalanması, } \\
\text { İMKB'de rekor yükseliş }\end{array}$ \\
\hline Mart 1999 & Düşüş & Mavi Çarşı Katliamı & $\begin{array}{l}\text { 1998-1999 Kosova Savaşı, } \\
\text { Yugoslavya, NATO'ya savaş ilan } \\
\text { etmesi ve Abdullah Öcalan'ın İmralı } \\
\text { Adası'na gönderilmesi }\end{array}$ \\
\hline Aralık 1999 & Düşüş & - & $\begin{array}{l}\text { IMF ile Stand-By anlaşması } \\
\text { imzalanması, Avrupa Birliği'nin } \\
\text { Türkiye'ye Helsinki Zirvesi'nde } \\
\text { adaylık teklif etmesi ve bazı } \\
\text { bankaların TMSF'ye devredilmesi }\end{array}$ \\
\hline $\begin{array}{l}\text { Mart-Nisan } \\
\quad 2000\end{array}$ & Yükseliş & - & $\begin{array}{c}\text { Cumhurbaşkanlığı seçim süreci } \\
\text { başlaması ve POAŞ'ın özelleştirilmesi }\end{array}$ \\
\hline Aralık 2000 & Düşüş & - & $\begin{array}{c}\text { Endekste düşüş, gecelik repo faizinde } \\
\text { artı̧, IMF yardım paketi, enflasyonda } \\
\text { düşüş, TCMB'nin döviz alma } \\
\text { politikası }\end{array}$ \\
\hline Şubat 2001 & Yükseliş & - & $\begin{array}{c}\text { Ekonomik kriz, siyasi } \\
\text { anlaşmazlıkların olması, dalgalı kur } \\
\text { politikası, TL'de devalüasyon }\end{array}$ \\
\hline May1s 2001 & Düşüş & & $\begin{array}{c}\text { Güçlü Ekonomiye Geçiş Programı'nın } \\
\text { uygulanması ve stand-by } \\
\text { anlaşmasının düzenlenmesi }\end{array}$ \\
\hline $\begin{array}{c}\text { Haziran- } \\
\text { Temmuz } 2001\end{array}$ & Yükseliş & - & $\begin{array}{l}\text { T.B.M.M'den Derviş Kanunu diye } \\
\text { adlandırılan ekonomi ile ilgili } \\
\text { kanunlar geçirilmesi }\end{array}$ \\
\hline Eylül 2001 & Düşüş & $\begin{array}{l}11 \text { Eylül saldırıları, } \\
\text { Taksim saldırısı }\end{array}$ & $\begin{array}{c}\text { Başbakanlıkta bir kriz toplantısının } \\
\text { yapılması }\end{array}$ \\
\hline Kasım 2002 & Düşüş & - & $\begin{array}{c}\text { Erken genel seçimler yapılmas1 ve } 58 . \\
\text { Hükümetin kurulmas1 }\end{array}$ \\
\hline
\end{tabular}




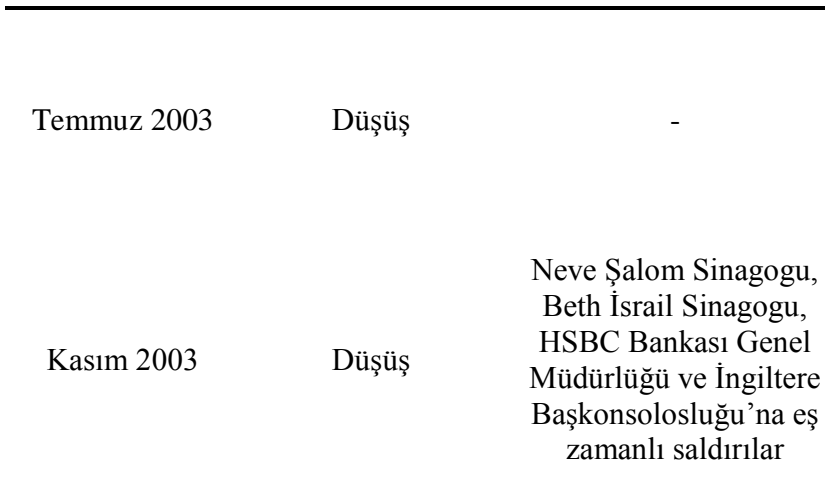

$\begin{array}{lcc}\text { Mart } 2004 & \text { Yükseliş } & - \\ \begin{array}{l}\text { Ağustos-Eylül } \\ 2004\end{array} & \text { Düşüş } & - \\ \text { Aralık 2004 } & \text { Düşüş } & - \\ & & \\ \text { Kasım } 2005 & \text { Düşüş } & \begin{array}{c}\text { Hakkari'de terör } \\ \text { saldır1ları }\end{array}\end{array}$

Aralık 2005 Düşüş

Haziran 2006 Düşüş

Ağustos 2007 Düşüş

Şubat 2008 Düşüş

Eylül $2008 \quad$ Yükseliş

Ekim 2008 Düşüş

Ocak 2009 Yükseliş

Mart 2011
İmar Bankası'nın TMSF'ye devredilmesi ve Kuzey Irak'ta yaşanan gerginlikler nedeniyle Türkiye-Amerika ilişkilerinin sarsilmas1

TCMB'nin ilk kez rekor zarar açıklaması, ihracatın artması

İMKB endeksinde rekor artış, uluslararası piyasalarda petrol fiyatlarının ilk kez psikolojik sınırı aşması

Katılım Öncesi Ekonomik Program açıklanması, İMKB'de rekor yükseliş,

Türkiye'nin, IMF ile ilk kez krize girmeden stand-by anlaşması, euronun dolar karşısında yükselmesi ve ilk kez bütçe fazlasının verilmesi

Türktelekom'un satılması ve Vakıfbank'ın halka arzı

TMSF'nin satışa çıkardığı Telsim'in Vodafone Telekomünikasyon A.Ş'ye ihale edilmesi

Doların rekor yükselişi ve TCMB'nin müdahalesi

ABD'de yaşanan Mortgage krizinin etkilerini azaltmak için piyasalara likitide verilmesi, İMKB endeksinin yılın en büyük kaybını yaşaması

TSK'nın PKK/KONGRA-GEL terör örgütüne sınır ötesi harekat yapması

ABD'de Lehman Brothers Inc. ve birçok banka ve şirketin iflas etmesi

Uluslararası mali kriz

İsrail'in Gazze'yi işgali, ABD'de Barack Obama'nın göreve başlaması, Hazine'nin açık vermesi ve İMKB endeksinde düşüş

Japonya'da deprem, Suriye'de iç savaş, Türkiye'nin -20'nin en hızlı büyüyen üçüncü ekonomisi olması 


\begin{tabular}{|c|c|c|c|}
\hline Eylül 2011 & Düşüş & - & $\begin{array}{c}\text { Türkiye'nin kredi notunun } \\
\text { yükselmesi, uluslararası piyasada altın } \\
\text { fiyatlarının düşmesi }\end{array}$ \\
\hline Mayis 2013 & Yükseliş̧ & $\begin{array}{l}\text { Reyhanl1-Hatay'da terör } \\
\text { saldırıları }\end{array}$ & $\begin{array}{l}\text { Gezi parkı olayları, Fed, tahvil } \\
\text { alımlarını azaltabileceğini açıklaması }\end{array}$ \\
\hline Eylül 2013 & Düşüş & - & $\begin{array}{l}\text { ABD Kongresi Başkan Obama'nın } \\
2014 \text { yılı bütçesini onaylamaması }\end{array}$ \\
\hline Ocak 2014 & Düşüş & - & $\begin{array}{l}\text { Fitch'in Türkiye'nin kredi notunu } \\
\text { değiştirmemesi, TCMB'nin kura ilk } \\
\text { kez doğrudan müdahalesi, Dolar/TL } \\
\text { paritesinin artması }\end{array}$ \\
\hline Temmuz 2015 & Yükseliş & Suruç saldırısı & $\begin{array}{l}\text { Türkiye'nin turizm gelirlerinin } \\
\text { azalması, Yunanistan'a yardım paketi }\end{array}$ \\
\hline Eylül 2015 & Düşüş & - & $\begin{array}{l}\text { Kurban Bayramı tatili dolayısıyla } \\
\text { dolar/TL tarihi zirvesini görmesi, } \\
\text { Fitch Ratings'in Türkiye'nin kredi } \\
\text { notunu "durağan" olarak teyit etmesi }\end{array}$ \\
\hline Ekim 2015 & Yükseliş & $\begin{array}{l}\text { Ankara'da Barış Mitingi } \\
\text { terör saldırısı }\end{array}$ & $\begin{array}{l}\text { Yeni Orta Vadeli Program'ın Resmi } \\
\text { Gazete'de yayımlanması }\end{array}$ \\
\hline
\end{tabular}

Kaynak: Türkiye'de Faaliyette Bulunan Günlük Gazeteler

\section{SONUÇ}

$\mathrm{Bu}$ çalışmada terörün volatiliteye etkisi Türkiye örneği üzerinden 1990-2015 y1llarını itibariyle GARCH yöntemi kullanılarak incelenmiştir. Çalışmada kullanılan BİST 100 endeksi aylık verileri, DATASTREAM veri sistemi üzerinden elde edilmiştir.

Borsa Endeksi Piyasa Getirilerinin (BEPG) orijinal ve logaritmik değerlerinde kırılma ve trend olduğu için serinin durağanlığını test amacıyla yapısal kırılmalı birim kök testi kullanılmıştır. Bu testin sonuçlarına göre borsa endeksi logaritmik değerlerinin birinci farkında durağan olduğu belirlenmiştir. Uygun ortalama eşitliğinin bulunması için ARMA maksimum olasılık modellemesi yapılmıştır ve en uygun ortalama eşitliği AR(2) ve MA(2) olarak bulunmuştur. Daha sonra ARCH-LM testi yardımıyla bu ortalama eşitliğinde anlamlı bir ARCH etkisi olmadığı test edilmiştir ve test sonucu anlamlı bir ARCH etkisi olduğunu göstermiştir. Bu nedenle borsa getirisinin koşullu varyansını ya da oynaklığını modelleyeceğimiz uygun GARCH modeli bulunmaya çalışılmıştır. Bu amaçla GARCH, EGARCH, PARCH ve Component GARCH modelleri tahmin edilmiştir. Bu GARCH modelleri arasında en yüksek olasılık (log likelihood) değeri ve en düşük Akakie, Schwarz ve Hannan-Quinn değerlerine sahip olduğu için Component GARCH modeli seçilmiştir ve volatilite grafiği elde edilmiştir. Sonraki aşamada CGARCH volatilite grafiğinde yer alan önemli ölçüde iniş ve çıkışların olduğu aylarda yer alan siyasi ve ekonomik gelişmelerin yanı sıra terör faaliyetleri de incelenmiştir. İnceleme sonucunda ele alınan aylarda terör faaliyetleri olmasına karşın borsa endeksi piyasa getirilerinde düşüşlerin yanı sıra yükselişlerinde olduğu tespit edilmiştir. Özellikle son dönemde gerçekleşen Ankara barış mitingi patlaması, Suruç patlaması ve Reyhanlı patlamasının olduğu aylarda da hem yükseliş hem düşüş olduğu saptanmıştır. 
Borsa Endeksi piyasa getirisi; savaşlar, diğer ülkelerde yaşanan önemli gelişmeler, Merkez Bankası kararları, ekonomik göstergelerdeki değişmeler gibi birçok faktörden etkilenmesine karşın terör faaliyetlerine genel olarak duyarsız kalmaktadır.

\section{KAYNAKÇA}

Abadie, A. ve Gardeazabal, J. (2003). "The economic costs of conflict: A case study of the Basque country". The American Economic Review, 93(1), 113-132.

Abadie, A. ve Gardeazabal, J. (2008). "Terrorism and the world economy”. European Economic Review, 52(1), 1-27.

Ağırman, E., Özcan, M. ve Yılmaz, Ö. (2014). “Terörizmin finansal piyasalara etkisi: Ampirik bir çalışma”. BDDK Bankacıllk ve Finansal Piyasalar, 8(2), 99-117.

Akıncı, M., Akıncı, G. Y. ve Yılmaz, Ö. (2014). "Terörizmin enflasyon ve ekonomik büyüme üzerindeki etkileri: Panel iki aşamalı en küçük kareler yöntemi”. Uluslararası Güvenlik ve Terörizm Dergisi, 5(1), 1-24.

Akıncı, M., Akıncı, G. Y. ve Yılmaz, Ö. (2015). "Terörizmin doğrudan ve dolaylı yatırımlar üzerindeki etkisi: Dış yatırımlar ne kadar telafi edici?". Ankara Üniversitesi SBF Dergisi, 70(1), 1 - 33.

Alp, İ. A. (2013). “Terörün ekonomik etkileri”. Uluslararası Güvenlik ve Terörizm Dergisi, 4(1), 1-19.

Altay, H., Ekinci, A. ve Peçe, M. (2013). “Ortadoğu'da terörün ekonomik etkileri: Türkiye, Mısır ve Suudi Arabistan üzerine bir inceleme”. Dumlupinar Üniversitesi Sosyal Bilimler Dergisi(37), 267-288.

Aslam, F. ve Kang, H.-G. (2013). "How different terrorist attacks affect stock markets". Defence and Peace Economics, 26(6), 634-648.

Bashir, U., Inam-ul-Hag. ve Gillani, S. A. (2013). "Influnce of terrorist activities on financial markets: Evidence from KSE”. Financial Assets and Investing, 5-13.

Becketti, S. ve Sellon, G. H. (1989). “Has financial market volatility increased?” Economic Review, 17-30.

Bollerslev, A. K., Engle, R. ve Nelson, D. (1994). ARCH models. Handbook of Economics, 2961-2984.

Bollerslev, T. (1986). Generalized autoregressive conditionally. ARCH selected readings. Oxford University Press.

Bollerslev, T. (2000). Generalized autoregressive conditional heteroskedasticity. ARCH selected readings. U.S.A.: Oxford University Press.

Dokuz Eylül Üniversitesi. (2005). Zaman Serisi Analizi ve Yapısal Kırılma. [Çevrim-içi: http://www.deu.edu.tr/userweb/onder.hanedar/dosyalar/KIRILMA.pdf], Erişim Tarihi: 03.06.2016.

Emsen, Ö. S. ve Değer, M. K. (2004). “Turizm üzerine terörizmin etkileri: 1984-2001 Türkiye deneyimi”. Akdeniz I.I.B.F. Dergisi, 7, 67-83.

Enders, W. (2004). Applied econometric time series (2nd ed.). New York: John Willey and Sons.

Enders, W., Sandler, T. ve Parise, G. F. (1992). "An econometric analysis of the impact of terrorism on tourism". Kyklos, 45(4), 531-554.

Engle, R. (2001). GARCH 101: "The use of ARCH/GARCH models in applied econometrics". Journal of Economic Perspectives, 15(4), 157-168.

Gujarati, D. N. (1995). Basic econometrics. U.S.A. :Mc-Graw-Hill Inc.

Gürsakal, S. (2009). "Varyans kırılması gözlemlenen serilerde GARCH modelleri: Döviz kuru oynaklığı örneği”. Erciyes Üniversitesi İktisadi ve İdari Bilimler Fakültesi Dergisi, (32), 319-337.

Güvenek, B. ve Alptekin, V. (2009). "Reel döviz kuru endeksinin otoregresif koşullu değişen varyanslılığının analizi: İki eşikli Tarch yöntemi ile modellenmesi”. Maliye Dergisi, 294-310.

Karolyi, G. A. ve Martell, R. (2010). "Terrorism and the stock market”. International Review of Applied Financial Issues and Economics, (2), 285-314.

Mazıbaş, M. (2015). IMKB piyasalarındaki volatilitenin modellenmesi ve öngörülmesi: Asimetrik GARCH modelleri ile bir uygulama. Ankara: Bankacılık Düzenleme Ve Denetleme Kurumu.

Nelson, D. (1991). “Conditional heteroskedasticity in asset returns: A new approach”. Econometrica, 347-370. 
Özer, M. ve Türkyılmaz, S. (2004). Türkiye finansal piyasalarında oynaklikların ARCH modelleri ile analizi. Eskişehir: T.C. Andolu Üniversitesi Yayınları.

Sandler, T. ve Enders, W. (2008). Economic consequences of terrorism in developed and developing countries: An overview (pp.17-47). Cambridge University Press.

Sevüktekin, M. ve Nargeleçekenler, M. (2005). Ekonometrik zaman serileri analizi. Nobel Yayın Dağıtım.

Sezgin, Ş., Gündüz, N. ve Sezgin, S. (2008).” Güneydoğu terör olaylarının ekonomik sonuçları”. Akademik Incelemeler, 3(1), 2-17.

Songül, H. (2010). Otoregresif koşullu değişen varyans modelleri: Döviz kurları üzerine bir uygulama. Ankara: Türkiye Cumhuriyet Merkez Bankasi.

Bahçeşehir Üniversitesi Stratejik Araştırmalar Merkezi. (2008). Türkiye'nin ulusal güvenliğine yönelik etnik ayrllıkçı terör tehdidinin analizi ve Irak'ın kuzeyinde bir Kürt devleti kurulmasına ilişsin değerlendirmesi. İstanbul: Araştırma Raporu.

Türkiye Barolar Birliği. (2006). Türkiye ve terörizm. (TBB Proje Grubu Raporu. No:107) Ankara: Türkiye Barolar Birliği Yayınları.

Uğurlu, E. (2015). Yapısal Kırılma Durumunda Birim Kök Sinamaları. [Çevrim-içi: https://www.researchgate.net/publication/281647172 Yapisal Kirilma Durumunda Birim Kok Sinamalari_Unit_Root_Test_Under_Structural_Break], Erişim Tarihi: 03.06.2016.

Eviews Help. Unit Root Tests With A Breakpoint. [Çevrim-içi: http://www.eviews.com/help/helpintro.html\#page/content\%2FadvtimeserUnit_Root_Tests_with_a_Breakpoint.html\%23wwconnect_header], Erişim Tarihi: 06.01.2016.

Yeşiltaş, M., Öztürk, İ., ve Türkmen, F. (2008). Terör faaliyetlerinin turizm sektörüne etkilerinin çözüm önerileri perspektifinde değerlendirilmesi. Sosyal Bilimler Dergisi, 10(1), 175-189.

Yıldız, Z., Yıldız, S., ve Aytemiz, L. (2015). "Kara turizm, terör turizmi ve Türkiye potansiyeli”. İnsan Ve Toplum Bilimleri Araştırmaları Dergisi, 4(2), 390-407.

Yurdakul, F. (2000). "Yapısal kırılmaların varlığı durumunda geliştirilen birim kök testleri”. G.Ü.İ.I.B.F. Dergisi, 2134. 